Egyptian Poultry Science Journal

http://www.epsaegypt.com

ISSN: 1110-5623 (Print) - 2090-0570 (On line)

\title{
BODY COMPOSITION, METABOLIC STATUS, IMMUNE RESPONSE AND INFLAMMATIONS IN RABBITS DURING LACTATION
}

\author{
M. M. Abdel-Aal; A. O. Abbas; O. G. Sakr; M. R. Ramadan and Nagwa A. Ahmed \\ Animal Production Department, Faculty of Agriculture, Cairo University, Giza, Egypt \\ Corresponding author: Mahmoud Abdel-Aal; E-mail: m_a.hassan@agr.cu.edu.eg
}

\author{
Received: 29/08/2016 \\ Accepted: 21/09/2016
}

\begin{abstract}
This experiment was carried out to investigate the influence of lactation on body composition, metabolic status, immune response and inflammation occurrence in $\mathrm{V}$ line doe rabbits. A total number of $30 \mathrm{~V}$-Line primiparous female rabbits were divided into two equal groups; $1^{\text {st }}$ group: females were kept as non-pregnant and non-lactating (NPNL, group) and $2^{\text {nd }}$ group: females were kept as lactating (L, group). Animals were fed $a d$ libitum a commercial pelleted diet contains $18.5 \%$ crude protein, $14.5 \%$ crude fiber, $2.5 \%$ fat and $2730 \mathrm{kcal} / \mathrm{kg}$ digestible energy. The number of suckling kits was adjusted to 8 per litter; the kits were weaned at 30 days. Average feed intake (g) was weekly recorded. Body composition of does was determined by BIA technique using bioelectrical body composition analyzer (Quantum II) apparatus. Blood samples were collected from does through three stages of lactation period; early (within 2-3 d post partum), mid (14 - $15 \mathrm{~d}$ of suckling) and late (30 d of suckling). Blood serum was assigned for total protein, albumin, glucose and cholesterol determinations. Globulin and albumin/globulin (A/G) ratio were calculated. Concentration of $\mathrm{T}_{3}$ hormone, Tumor Necrosis Factor - Alfa (TNF- $\alpha$ ) and Inerleukin 2 (IL-2) were estimated by using ELISA technique. The results illustrated that feed intake of does significantly increased during lactation period. In L does, body content of humidity, protein and ash were significantly higher; in contrast, fat and energy content were significantly lower. No significant differences were found in cholesterol, glucose, albumin, $\mathrm{A} / \mathrm{G}$ ratio, $\mathrm{T}_{3}$ and $\mathrm{TNF}-\alpha$ through stages of lactation. While, significant differences were obtained in total protein, globulin and IL-2 at mid and late stages compared to early stage of lactation.
\end{abstract}

In conclusion, stressed does, which suckle high number of pups $(\mathrm{n} \geq 8)$ should be kept under especial nutritional care because energy balance is negative during lactation and fat stores are mobilized, especially in primiparous does.

Key Words: Rabbits-Body Composition- Lactation- Metabolic Status. 


\section{INTRODUCTION}

Female rabbits in commercial farms are always gestating, suckling or both gestating and suckling at the same time; these two physiological functions, especially lactation, are very costly in term of energy. In reproductive rhythms commonly used in rabbits, where the gestation and lactation overlap, the rabbit is not able to consume enough feed to meet their needs (Pascual et al., 2002; Costa et al., 2004; Xiccato et al., 2004 and Quevedo et al., 2005). To maximize reproductive performance of does, it should not forget that ovarian activity is optimized when the animal has enough energy reserves which in turn, affect animal production in the long term (Quevedo et al., 2005 and Theilgaard et al ., 2006).

Blood constituents have been used by many investigators as a monitor for genetic makeup, health and nutrition (Azoz and ElKholy, 2005). In addition, hormonal and metabolite rate were considered as a good indicator for understanding the physiological requirements for efficient reproduction (Cardinali et al., 2009).

Thus, the aim of this study was to investigate the influence of lactation on body condition, metabolic status, immune response and inflammation occurrence in V-line doe rabbits.

\section{MATERIALS AND METHODS}

This study was carried out in the private rabbitry of $6^{\text {th }}$ October city, El-Wahat road, Giza, Egypt, during the period from July up to December, 2015. A total number of 30 V-Line primiparous female rabbits aging 6 - 7 months were divided into two equal groups; $1^{\text {st }}$ group: females were kept as non-pregnant and non-lactating (NPNL, group; average of body weight was $3440 \mathrm{~g}$ ) and $2^{\text {nd }}$ group: females were kept as lactating (L, group; average of weight was $3730 \mathrm{~g}$ ). Does were housed in individual cages of commercial type provided with feeders, automatic nipple drinkers and nestboxes. Animals were fed ad-libitum a commercial pelleted diet with $18.5 \%$ crude protein, $14.5 \%$ crude fiber and $2.5 \%$ fat. Calculated digestible energy of the diet was $2730 \mathrm{kcal} / \mathrm{kg}$ digestible energy. All does were kept under the same managerial and hygienic conditions. After kindling the number of suckling kits were adjusted to 8 per/doe and weaned at 30 days. Feed intake (g) was weekly recorded.

Bioelectrical impedance analysis (BIA) technique was used to determine in vivo chemical body composition of does (humidity, g and \%; protein, $\mathrm{g}$ and \% DM; ash, $\mathrm{g}$ and \% DM; fat, $\mathrm{g}$ and \% DM; energy, MJ and kJ/100g DM) according to methodology and equations obtained by Pereda (2009), using bioelectrical body composition analyzer (Quantum II) apparatus.

Blood samples were collected from marginal ear vein of does into clean centrifuge tubes at different stages through lactation period; early (within 2-3 d post partum; $n=9)$, mid $(14-15 \mathrm{~d}$ of suckling; $\mathrm{n}=6$ ) and late (30 d of suckling, before weaning; $n=6$ ). Blood serum was assigned for total protein, albumin, glucose and cholesterol determinations. Methods of analysis were done according to the procedure described by the manufacturers. Globulin and albumin/globulin (A/G) ratio was also calculated.

Concentration of total $\mathrm{T}_{3}$ hormone was determined by ELISA technique using the coated tubes kits of Immunospec Corporation, USA. Also, concentration of Tumor Necrosis Factor - Alfa (TNF- $\alpha$, $\mathrm{pg} / \mathrm{ml}$ ) and Inerleukin 2 (IL-2, pg/ml) were estimated by using TNF- $\alpha$ and IL-2 ELISA kits obtained from WKEA MED SUPPLIES CORP, China.

Data were statistically analyzed using the General Linear Model Program of SAS 
(2004) according to the following one way analysis model: $\mathrm{Y}_{\mathrm{ij}}=\mu+\mathrm{Tr}_{\mathrm{i}}+\mathrm{e}_{\mathrm{ij}}$

Where, $Y_{i j}=$ any observation of $j^{\text {th }}$ animal within $i^{\text {th }}$ treatment, $\mu=$ overall mean, $\operatorname{Tr}_{i}=$ effect of $i^{\text {th }}$ treatment (i: $1-2$ ) and $e_{i j}=$ experimental error. Duncan Multiple Range Test (Duncan, 1955) was used to test the level of significant differences among means.

Results

\section{Feed intake}

The results illustrated that feed intake of does significantly increased during lactation period. Total feed consumption of lactating does (L) was more than nonpregnant non-lactating does (NPNL) by about $118 \%$ (Fig. 1, a). Moreover, lactation period (4 weeks) associated with gradually significant increase in feed intake reached at the fourth week of lactation to more than $100 \%$ of feed intake at the first week of lactation (Fig. 1, b). The highest value of increasing feed intake was found from the $3^{\text {rd }}$ week to $4^{\text {th }}$ week of lactation $(+31.7 \%)$.

\section{Body composition:}

The results showed that body content of humidity, protein and ash $(\mathrm{g})$ of $\mathrm{L}$ does were significantly higher than that of NPNL does (Table 1). The differences between NPNL and L does were $402.24 \mathrm{~g}$ (11.9\%), $21.07 \mathrm{~g} \mathrm{(3 \% )} \mathrm{and} 8.51 \mathrm{~g}(7.2 \%)$ in body content of humidity, protein and ash $(\mathrm{g})$, respectively. In contrast, fat content (g) and energy (MJ) were significantly lower in body of L does than that of NPNL does by $97.69 \mathrm{~g}(20.6 \%), 2.71 \mathrm{MJ}(6.8 \%)$, respectively (Table 1 ).

On the other hand, results obtained herein declared that body composition in percentages and grams had a similar trend whereas the body percentage of humidity, ash and protein were significant increase (+ $3.9,0.1$ and $0.2 \%$, respectively) in L does as compared to NPNL does (Fig. 2; a, b and c). However, significant decreases were observed in body fat $(-1.7 \%)$ and body energy of L does (- $198.8 \mathrm{~kJ} / 100 \mathrm{~g}, 21.5 \%$ ) when compared with NPNL does.

\section{Metabolic status}

Blood metabolites of $\mathrm{V}$-line doe rabbits throughout lactation period (early, mid and late) were presented in table (2). Values of all metabolites were within normal range of rabbits. No significant differences in cholesterol, glucose, albumin and albumin/globulin ratio were found through stages of lactation. However, significant differences were shown in total protein and globulin between mid and late stages of lactation (Table 2).

During lactation, no significant changes were obtained in $\mathrm{T}_{3}$ concentration (Fig. 3 ). However, the highest level of $\mathrm{T}_{3}$ concentration was determined at mid stage of lactation; the level was higher by about $14.3 \%$ compared to early and late stages of lactation.

\section{Inflammatory and immune responses}

The effect of lactation stage on serum tumor necrosis factor alpha (TNF- $\alpha$ ) concentration is shown in figure $(4, a)$. The current investigation demonstrated that the lactation stages had no significant effects on serum TNF- $\alpha$ concentration. However, the highest value of TNF- $\alpha$ was found in the late stage of lactation (Fig. 4, a).

The effect of lactation stage on serum inetrleukin-2 (IL-2) concentration is shown in figure $(4, \mathrm{~b})$. The serum IL-2 levels showed significant elevation during the medium and late stages compared to early stage of lactation by about 9.9 and $8.2 \%$; respectively. However, the serum IL-2 concentrations did not significantly vary within the last two stages of lactation (Fig. $4, b)$.

\section{DISCUSSION}

Total feed intake of does significantly increased during lactation period (Fig. 1, a $\&$ b). In contrast, lactation associated with a significant decrease in body fat and energy content (Table 1 and Fig. 2, e). In this respect, Fortun-Lamothe (2006) noted 
that, if rabbit does keep following the intensive reproductive rhythm, with insemination every 35 or 42 days, they must meet strong nutritional needs. Indeed, lactation is very costly in terms of energy consequently energy deficit, which occurs during lactation. On the other hand, FortunLamothe (2006) and Pereda et al. (2009) reported that during the first and second lactation, negative energy balances are produced despite the mobilization of body reserves.

The results of this study showed increasing of total protein, albumin and globulin at late stage of lactation (Table 2). Increasing in total proteins, albumin and globulin may reflect changes in the hepatic function; whereas the change in albumin level reflects the change in liver function (Azoz and El-Kholy, 2005). Jones and Bark (1979) reported that the liver is the site of albumin synthesis; meanwhile, lymphatic tissues form globulin. The decrease in A/G ratio of does seems to be due to the increase in globulin rather than the decrease in albumin. This may reflect the positive increase in the immunity through increasing the $\gamma$-globulin (More et al., 1980). Furthermore, Ismail et al. (2002) reported that the lowest value of $\mathrm{A} / \mathrm{G}$ ratio was a good indicator for increasing the immunoglobulin.

No significant difference in glucose was found through stages of lactation (Table 2). In this respect, Cardinali et al. (2009) reported that glucose level did not detect any significant variation in nulliparous (only gestation effect) and primiparous (overlapping of gestation and lactation) does. This can explain the homeostatic mechanisms that controlling the glycaemia. Glucose may be a good indicator of the energy balance of animals (FortunLamothe, 2006). Jones and Parker (1988) found that, in rabbits, mammary gland also uses glucose for the synthesis of milk lipids. On the other hand, the blood glucose levels are even lower in rabbits, which are simultaneously gestating and lactating (Fortun, 1994).

During lactation, there were no significant changes obtained in $\mathrm{T}_{3}$ concentration (Fig. 3), Cardinali et al. (2009) concluded that blood $\mathrm{T}_{3}$ concentration decreased in primiparous does (overlapping of gestation and lactation), that may be to ascribe the energy deficit caused by milk production, responsible for intense energy mobilization. The transition from late pregnancy to lactation is a time of great physiological stress. Feed intake was decline just before parturition, this coupled with the rapid increase in energy requirements during lactogenesis. After that significant increase in feed intake was observed all over lactation period to release stored nutrients and direct them to the mammary gland. This mechanism realized body homeorhesis (Bauman and Currie, 1980).

Pregnancy and lactation are associated with immune regulation and reduced $\mathrm{Th}_{1}$ responses (Denney et al., 2011). Hormonal changes during pregnancy, which persist in part during lactation, are one cause of this immune shift (Cutolo et al., 1995). Lactation have been shown to be associated with B-cell production and reduced inflammatory responses (Yu-Lee, 2002). However, results reported herein showed that all stages of lactation had no significant effects on serum TNF- $\alpha$.

Increasing serum IL-2 during the last two stages of lactation is a good indicator for stimulating the immune response. IL-2 signals influence various lymphocyte subsets during differentiation, immune responses and homeostasis. Stimulation with IL-2 is crucial for the maintenance of regulatory $\mathrm{T}\left(\mathrm{T}_{\mathrm{Reg}}\right)$ cells (Malek, 2008) and for the differentiation of $\mathrm{CD}^{+}{ }^{+} \mathrm{T}$ cells into defined effector $\mathrm{T}$ cell subsets following antigen-mediated activation (Martins et al., 2008). For $\mathrm{CD}^{+} \mathrm{T}$ cells, IL-2 signals optimize both effector $\mathrm{T}$ cell generation and differentiation into memory cells (Boyman et al., 2010). Use of IL-2 - either 
alone or in complex with particular neutralizing IL-2-specific antibodies - can amplify $\mathrm{CD}^{+} \mathrm{T}$ cell responses or induce the expansion of the $\mathrm{T}_{\mathrm{Reg}}$ cell population (Jin et al., 2008).

\section{CONCLUSION}

It can concluded that, stressed does, which suckle high number of pups $(\mathrm{n} \geq 8)$ should be kept under especial nutritional care because energy balance is negative during lactation and fat stores are mobilized, especially in primiparous does.

\section{Acknowledgements}

This work was supported by EgyptianSpinach project titled "Raise the level of low income families and activate the role of woman in community development through the use of modern technologies in the project of rabbits in Egypt"

Table (1): Body composition of V-line lactating doe rabbits

\begin{tabular}{|l|l|l|}
\hline \multirow{2}{*}{ Item } & \multicolumn{2}{|c|}{ Reproductive status of doe } \\
\cline { 2 - 3 } & \multicolumn{1}{|c|}{ NPNL } & \multicolumn{1}{c|}{$\mathbf{L}$} \\
\hline Humidity, g & $3372.47^{\mathbf{b}} \pm 24.44$ & $3774.71^{\mathbf{a}} \pm 68.28$ \\
Ash, g & $117.70^{\mathbf{b}} \pm 0.48$ & $126.21^{\mathbf{a}} \pm 1.23$ \\
Protein, g & $708.58^{\mathbf{b}} \pm 3.40$ & $729.65^{\mathbf{a}} \pm 9.49$ \\
Fat, g & $571.66^{\mathbf{a}} \pm 10.82$ & $473.97^{\mathbf{b}} \pm 32.04$ \\
Energy, MJ & $42.67^{\mathbf{a}_{ \pm}} \pm 0.53$ & $39.96^{\mathbf{b}_{ \pm}}+1.57$ \\
\hline
\end{tabular}

a, b Means with different superscripts within the same row are significantly different $(\mathrm{P}<0.05)$. $\mathrm{NPNL}=$ non-pregnant non-lactating doe rabbits and $\mathrm{L}=$ lactating doe rabbits.

Table (2): Blood metabolites of V-line doe rabbits throughout stages of lactation

\begin{tabular}{|l|l|l|l|}
\hline \multirow{2}{*}{ Item } & \multicolumn{3}{|c|}{ Stages of lactation } \\
\cline { 2 - 4 } & \multicolumn{1}{|c|}{ Early } & \multicolumn{1}{c|}{ Mid } & \multicolumn{1}{c|}{ Late } \\
\hline Cholesterol, mg/dl & $33.12 \pm 2.67$ & $32.86 \pm 1.61$ & $26.23 \pm 2.83$ \\
Glucose, $\mathrm{mg} / \mathrm{dl}$ & $72.62 \pm 3.81$ & $62.70 \pm 3.55$ & $71.19 \pm 4.95$ \\
Total protein, g/dl & $6.32^{\mathbf{a b}_{ \pm}} \pm 0.06$ & $5.85^{\mathbf{b}} \pm 0.20$ & $6.73^{\mathrm{a}} \pm 0.42$ \\
Albumin, g/dl & $2.93 \pm 0.08$ & $2.89 \pm 0.12$ & $3.13 \pm 0.22$ \\
Globulin, g/dl & $3.39^{\mathbf{a b}_{ \pm}} \pm 0.04$ & $2.96^{\mathbf{b}} \pm 0.09$ & $3.60^{\mathbf{a}} \pm 0.34$ \\
A/G ratio & $0.86 \pm 0.03$ & $0.97 \pm 0.03$ & $0.89 \pm 0.09$ \\
\hline
\end{tabular}

a, b Means with different superscripts within the same row are significantly different $(\mathrm{P}<0.05)$. 


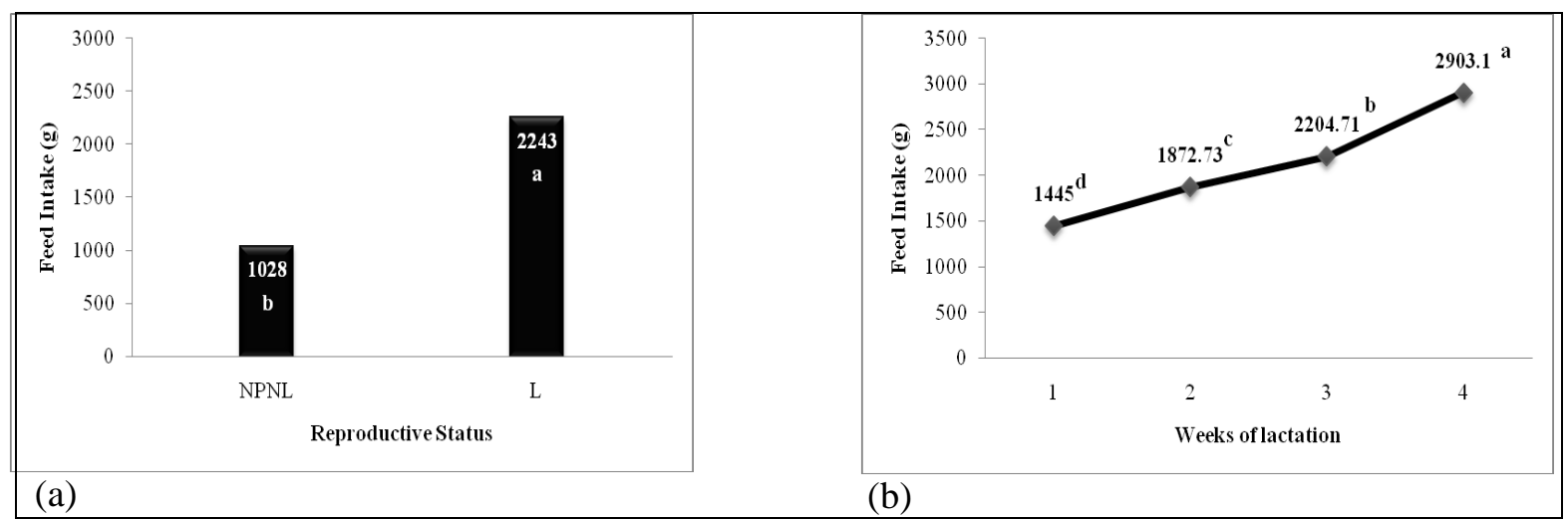

Fig. 1 (a \& b). Feed intake of V-line lactating does during lactation.

$\mathrm{a}, \mathrm{b}, \mathrm{c}, \mathrm{d}$ Means with different superscripts are significantly different $(\mathrm{P}<0.05)$. NPNL $=$ non-pregnant nonlactating does and $\mathrm{L}=$ lactating does.

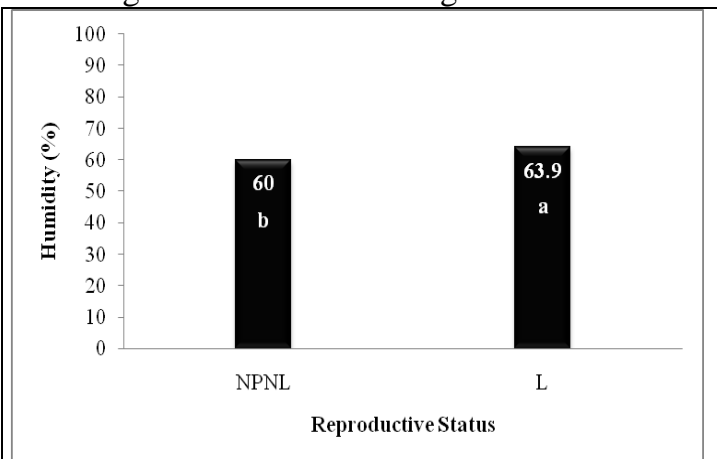

(a) Humidity

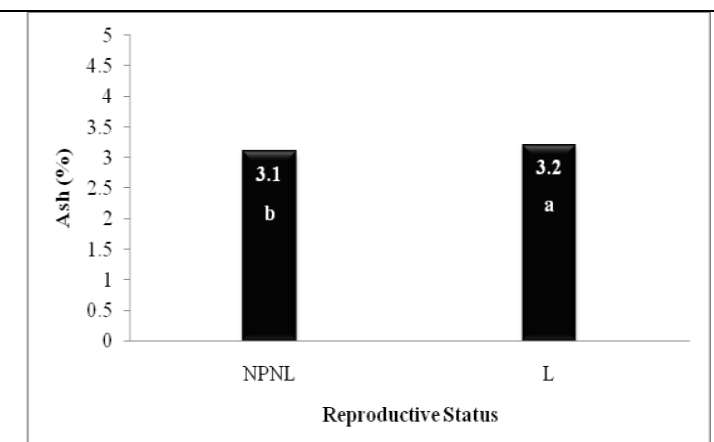

(b) Ash

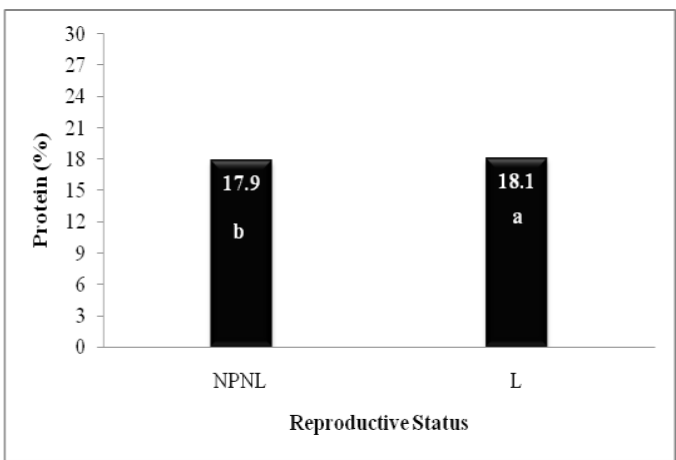

(c) Protein

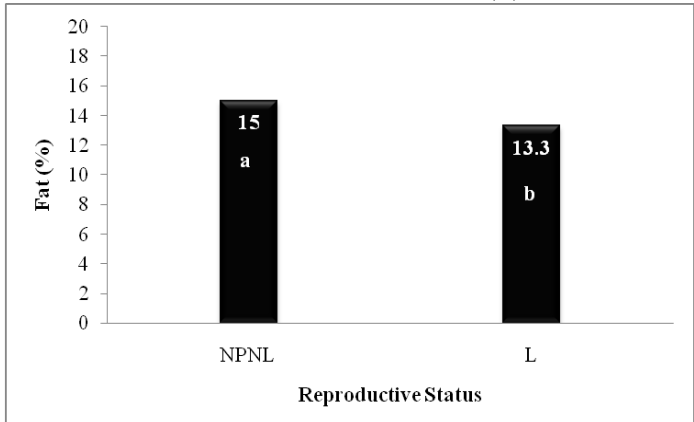

(d) Fat

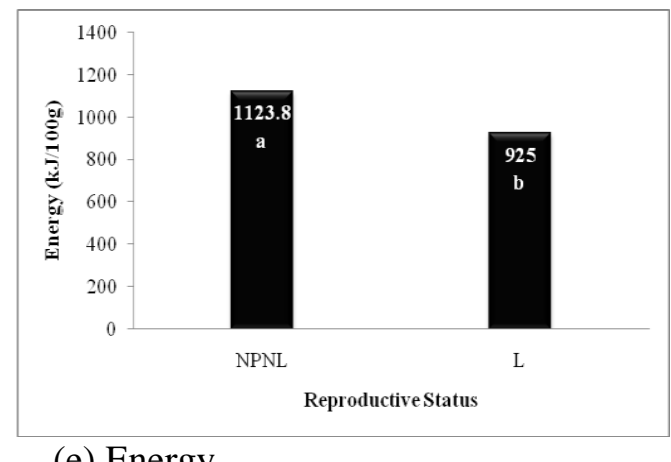

Fig. 2. Body composition of $\mathrm{V}$-line lactating doe rabbits.

a, $b$ Means with different superscripts are significantly different $(\mathrm{P}<0.05)$. NPNL $=$ non-pregnant nonlactating doe rabbits and $\mathrm{L}=$ lactating doe rabbits. 


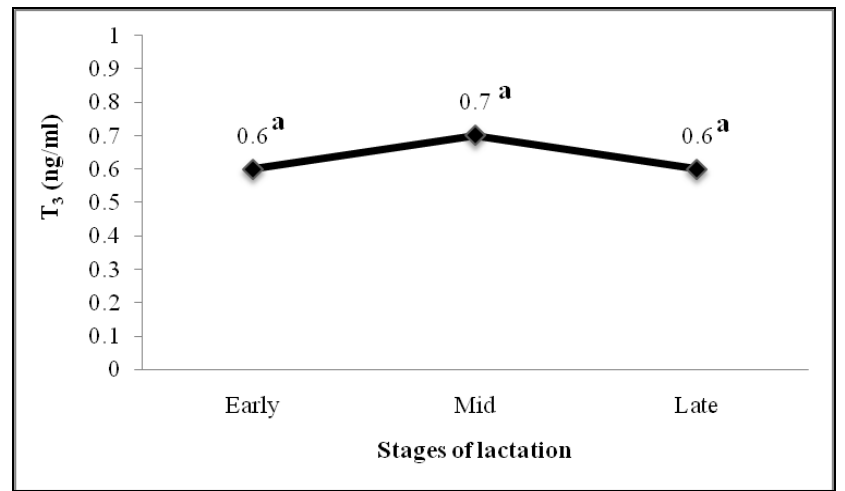

Fig. 3. $\mathrm{T}_{3}$ concentration of $\mathrm{V}$-line doe rabbits throughout stages of lactation

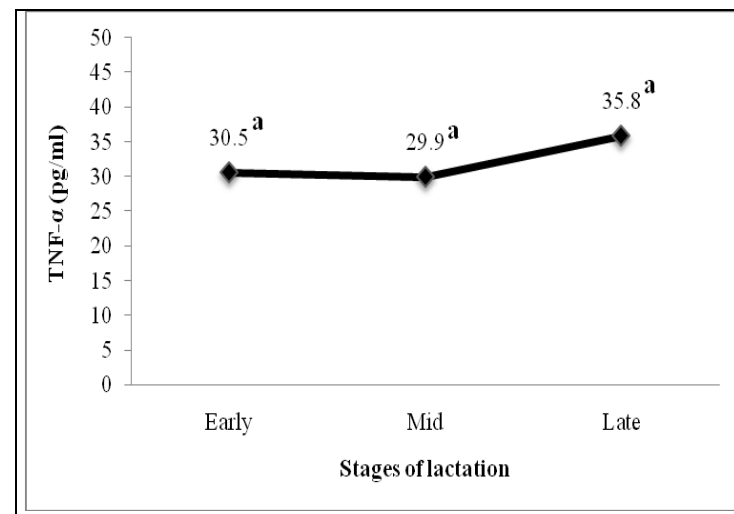

(a) TNF- $\alpha$

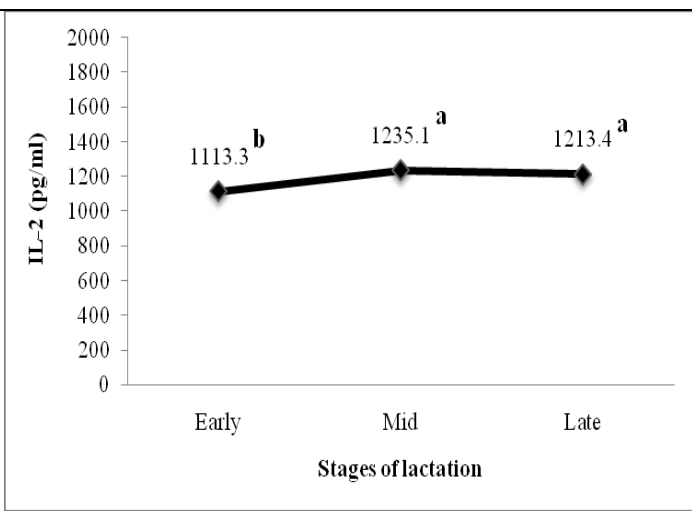

(b) IL-2

Fig. 4. TNF- $\alpha$ and IL-2 concentrations of $V$-line doe rabbits throughout stages of lactation $a, b$, Means with different superscripts are significantly different $(\mathrm{P}<0.05)$. 


\section{REFERENCES}

Azoz, A. A.; and El-Kholy, K. H. 2005. Blood metabolites and hormones of $\mathrm{V}$ line and Buscat female rabbits under middle Egypt conditions. Egyptian J. Rabbit Sci., 15 (2): 131-142.

Bauman, D. E.; and Currie, W. B. 1980. Partitioning of nutrients during pregnancy and lactation: A review of mechanisms involving homeostasis and homeorhesis. J. Dairy Sci.; 63 (9): 15141529.

Boyman, O.; Cho, J.; and Sprent, J. 2010. The role of interleukin-2 in memory CD8 cell differentiation. Adv. Exp. Med. Biol., 684: 28-41.

Cardinali, R.; Dal Bosco, A.; Castellini, C.; Boiti, C.; and Brecchia, G. 2009. Serum level of hormone and metabolites in pregnant rabbit does. Italian J. Anim. Sci., 8 (2): 778-780.

Costa, C.; Baselga, M.; Lobera, J.; Cervera, C.; and Pascual, J. 2004. Evaluation response to selection and nutritional needs in a three way cross in rabbits. J. Anim. Breed. Genet., 121: 186-196.

Cutolo, M.; Sulli, A.; Seriolo, B.; Accardo, S.; and Masi, A. 1995. Estrogens, the immune response and autoimmunity. Clin. Exp. Rheumatol., 13: 217-222.

Denney, J.; Nelson, E.; Wadhwa, P.; Waters, T.; Mathew, L.; Chung, E.; Goldenberg, R.; and Culhane, J. 2011. Longitudinal modulation of immune system cytokine profile during pregnancy. Cytokine, 53 (2): 170-177.

Duncan, D. B. 1955. Multiple range and multiple F-test. Biometrics, 11: 1-42.

Fortun, L. 1994. Les effets de la lactación sur la mortalite et la croissance foetales chez la lapine primipare. These de Doctorat, Universite de Rennes I, 194 pp.

Fortun-Lamothe, L. 2006. Energy balance and reproductive performance in rabbit does: a review. Anim. Reprod. Sci., 93 (1-2): 1-15.

Ismail, A. M.; Abou-El-Ella, M. A.; and Sedki, A. A. 2002. Blood metabolites, growth and reproductive performance and immune responsiveness in growing and doe rabbits as affected by acitrol treatments. Egyptian J. Agric. Sci., 80: 1789-1808.

Jin, G.; Hirano, T.; and Murakami, M. 2008. Combination treatment with IL-2 and anti-IL-2 mAbs reduces tumor metastasis via NK cell activation. Int. Immunol., 20: 783-789.

Jones, E. A.; and Bark, P. D. 1979. Chemical Diagnosis of Disease. Brown, S. S.; Mitchell, F. L.; and Young, D. S. (Eds). Elsevier, Biomedical Press, Amsterdam, New York, Oxford, 325363.

Jones, C. S.; and Parker, D. S. 1988. Mammary blood flow and cardiac output during initiated involution of the mammary gland in the rabbit. Comp. Biochem. Physiol. 91: 21-25.

Malek, T. R. 2008. The biology of interleukin-2. Annu. Rev. Immunol., 26: 453-479.

Martins, G.; Cimmino, L.; Liao, J.; Magnusdottir, E.; and Calame, $\mathbf{K}$. 2008. Blimp-1 directly represses IL2 and the IL-2 activator Fos, attenuating T cell proliferation and survival. J. Exp. Med., 205: 1959-1965.

More, T.; Rai, A. K.; and Singh, M. 1980. Note on effect of thermal exposure on body fluid composition of different breeds and carcasses of sheep. Indian J. Anim. Sci., 50: 207-209.

Pascual, J.; Motta, W.; Cervera, C.; Quevedo, F.; Blas, E.; and FernándezCarmona, J. 2002. Effect of dietary energy source on the performance and perirenal fat thickness evolution of primiparous rabbit does. Anim. Sci., 75: 267-279. 
Pereda, N. 2009. Estudio de sistemas de manejo reproductivo de la coneja relacionados con su condición corporal. Tesis doctoral, Universidad Politécnica De Madrid, Spain. pp: 201.

Pereda, N.; Nicodemus, N.; and Rebollar, P. 2009. Evaluación de la técnica de análisis de impedancia bioeléctrica (BIA) para estimar la composición corporal en conejas reproductoras. Boletin de cunicultura, 159: 14-21.

Quevedo, F.; Cervera, C.; Blas, E.; Baselga, M.; Costa, C.; and Pascual, J. 2005. Effect of selection for litter size and feeding program on the development of rearing rabbit does. Anim. Sci., 80: 161-168.
SAS, 2004. SAS Institute Inc. SAS/STAT ${ }^{\circledR}$ 9.1 User's Guide. Cary, NC, USA.

Theilgaard, P.; Sánchez, J.; Pascual, J.; Friggens, N.; and Baselga, M. 2006. Effect of body fatness and selection for prolificacy on survival of rabbit does assessed using a cryopreserved control population. Livest. Sci., 103: 65-73.

Xiccato, G.; Trocino, A.; Sartori, A.; and Queaque, P. 2004. Effect of parity order and litter weaning age on the performance and body energy balance of rabbit does. Livest. Prod. Sci., 85: 239251.

Yu-Lee, L. Y. 2002. Prolactin modulation of immune and inflammatory responses. Recent Prog. Horm. Res., 57: 435-455. 


\section{تركيب الجسم، حالة التمثيل الغذائي، الإستجابة المناعية العربي والإلتهابات في الأرانب خلال فترة

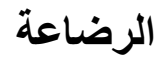

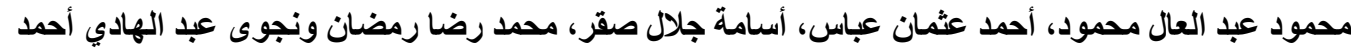

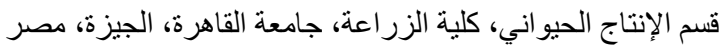

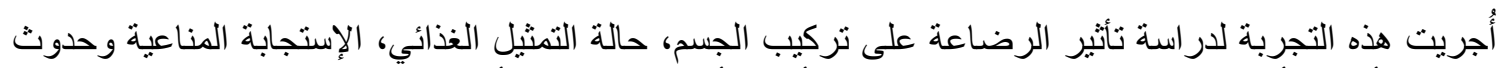

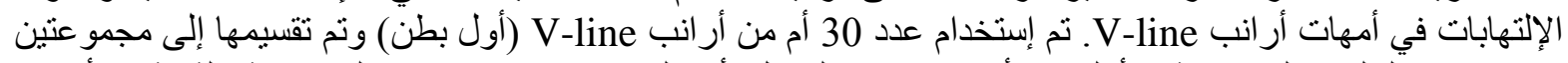

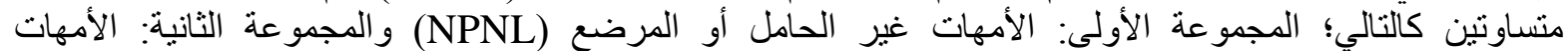

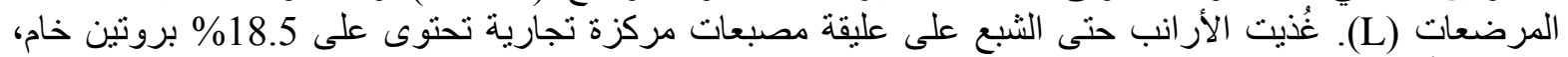

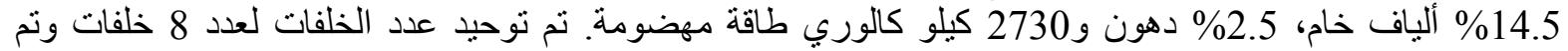
فطامها على عمر 30 يوم.

تم تسجيل كمية العلف المأكول إسبو عياً. تم تقدير مكونات الجسم بتقنية BIA بإستخدام جهاز تقدير مكونات الجسم (Quantum II)

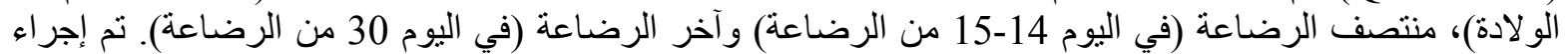

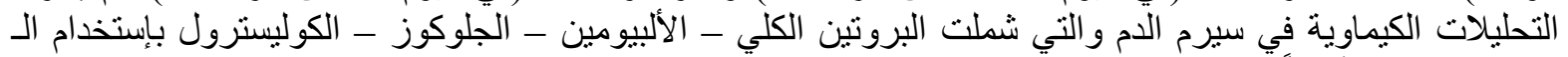

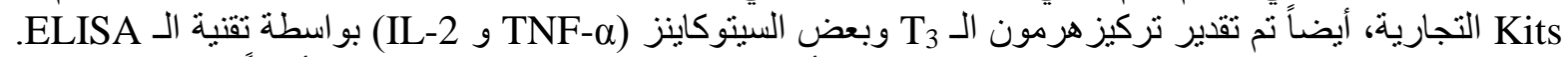

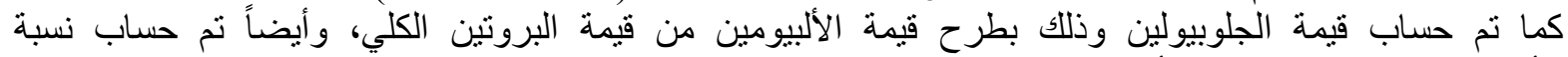

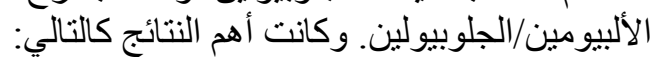

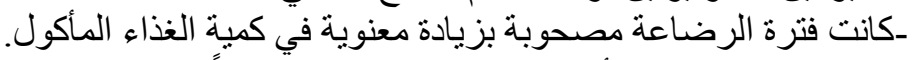

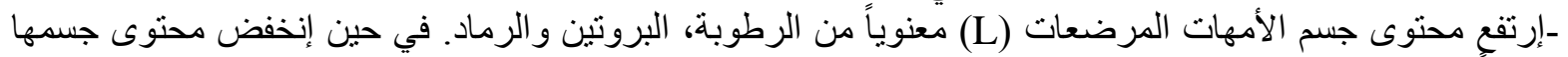
معنوياً من الدهن و والطاقة.

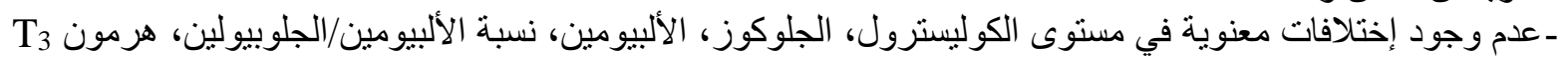

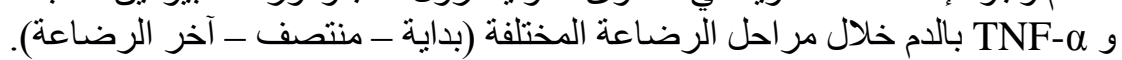

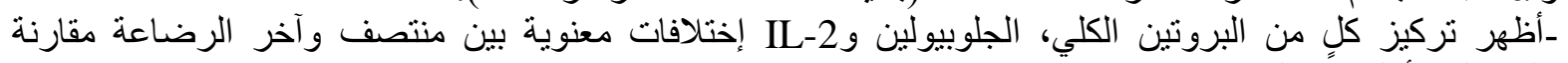
بالمرحلة الأولى من الريز كن الرضاعة .

يُستنتج من هذه الدراسة أنه يجب وضع أمهات الأرانب (أول بطن) التي تُرضع أكثر من 8 خلفات تحت نظام غذائي

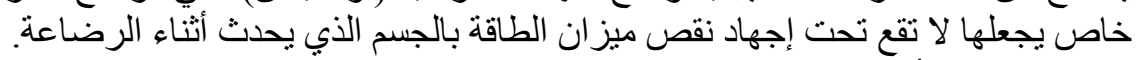
الكلمات الدالة: الأر انب، تركيب الجسم، الرضاد نقاعة، التمثيل الغذائي. 